Buletin JSJ, 3 (1), 2021, 43-51

Available online di: http://ejournal-balitbang.kkp.go.id/index.php/JSJ/index

\title{
ESTIMASI KARBON PADA MANGROVE DI KABUPATEN BELITUNG PROVINSI KEPULAUAN BANGKA BELITUNG
}

\section{ESTIMATION OF CARBON MANGROVES IN BELITUNG REGENCY, BANGKA BELITUNG ISLANDS}

\author{
Isviana Dwi Karyati ${ }^{1}$, Acacia Zeny ${ }^{1}$, Araminta Mourniaty ${ }^{1)}$, Dadan Zulkifli ${ }^{1)}$, Hendra Irawan ${ }^{1)}$ \\ ${ }^{1}$ Prodi Teknologi Pengelolaan Sumberdaya Perairan Sekolah Tinggi Perikanan \\ JI. AUP No. 1 Pasar Minggu-Jakarta Selatan; Telepon +21-7805030 Jakarta 12520 \\ ^Email : isvianadwik@gmail.com, acaciazeny08@gmail.com
}

\begin{abstract}
ABSTRAK
Mangrove merupakan salah satu formasi hutan yang habitatnya berada di perbatasan daratan dan lautan. Secara umum mangrove berfungsi sebagai tempat berkumupulnya berbagi macam biota laut, tempat mencari makan, tempat pemijahan, dan juga sebagai tempat asuhan berbagai macam biota. Mangrove juga memiliki fungsi secara fisik, yaitu sebagai penahan gelombang tsunami, panahan amukan angin dan untuk menahan erosi. Hutan mangrove memiliki peran yang sama dengan hutan yang lainnya untuk penyerap karbon dioksida $\left(\mathrm{CO}_{2}\right)$ sehingga dapat membantu dalam pencegahan perubahan iklim. Mangrove memberi sumbangan sangat potensial untuk mengurangi emisi karbon dibanding hutan hujan tropis. Tujuan dari penelitian ini adalah untuk menduga serapan karbon (C) pada vegetasi mangrove di kawasan mangrove Kabupaten Belitung. Penelitian ini dilakukan pada tanggal 2 Maret sampai 15 Mei 2020, di kawasan mangrove Kecamatan Sijuk, Kecamatan Tanjung Pandan dan Kecamatan Membalong. Metode sampling yang digunakan dalam penelitian ini adalah Metode Purposive sampling untuk menentukan tiga stasiun pengamatan. Hasil dari penelitian ini menunjukkan bahwa mangrove pada Kecamatan Sijuk dengan simpanan carbon 182,59 Ton C/ha dengan kerapatan 1.650,13 pohon/ha kemudian Kecamatan Membalong dengan simpanan carbon 168,62 Ton C/ha dengan kerapatan 1411,82 pohon/ha dan simpanan carbon terendah terdapat pada Kabupaten Tanjung Pandan dengan simpanan carbon 38,56 Ton C/ha dengan kerapatan 1.249,33 pohon/ha. Serapan karbon mangrove Rhizophora apiculata sebesar 217,28 g/pohon dan Rhizophora mucronata 441,8 g/pohon.
\end{abstract}

Kata Kunci: mangrove, stok karbon, Belitung.

\begin{abstract}
Mangroves are one of the forest formations whose habitat is on the border of the land and sea. In general, mangroves function as a place for gathering various kinds of marine life, a place to look for food, a place for spawning, and also as a place to care for various types of biota. Mangroves also have physical functions, namely as a barrier to tsunami waves, wind raging arrows and to resist erosion. Mangrove forests have the same role as other forests for absorbing carbon dioxide $\left(\mathrm{CO}_{2}\right)$ so that they can help in preventing climate change. Mangroves make a very potential contribution to reducing carbon emissions compared to tropical rain forests. The purpose of this study is to estimate carbon stock $(C)$ in mangrove vegetation in the rove Belitung Regency mangrove area. This research was conducted from March 2 to Mei 15, 2020, in the mangrove area of Sijuk District, district Tanjung Pandan and District Membalong. The sampling method used in this study is the Purposive sampling method to determine the three observation stations. The results of this study showed that mangroves in Sijuk District with carbon stock 182,59 Tons C /ha with density 1650.13 trees/ha then District Membalong with carbon stock 168,62 tons C / ha with densities of 1411.82 trees/ha and the lowest carbon stock are in Tanjung Pandan District with carbon stock of 38,56 tons C/ha with densities 1249.33 trees/ha. Carbon sequestration capability from mangroves Rhizophora apiculata 217,28 $\mathrm{g} /$ tree and Rhizophora mucronata $441,8 \mathrm{~g} /$ tree
\end{abstract}

Keywords: mangrove, carbon stock, Belitung 
Available online di: http://ejournal-balitbang.kkp.go.id/index.php/JSJ/index

\section{PENDAHULUAN}

Mangrove merupakan salah satu formasi hutan yang habitatnya berada di perbatasan daratan dan lautan. Secara umum mangrove berfungsi sebagai tempat berkumupulnya berbagi macam biota laut, tempat mencari makan, tempat pemijahan, dan juga sebagai tempat asuhan berbagai macam biota. Mangrove juga memiliki fungsi secara fisik, yaitu sebagai penahan gelombang tsunami, panahan amukan angin dan untuk menahan erosi. Hutan mangrove memiliki peran yang sama dengan hutan yang lainnya untuk penyerap karbon dioksida $\left(\mathrm{CO}_{2}\right)$ sehingga dapat membantu dalam pencegahan perubahan iklim. Mangrove memberi sumbangan sangat potensial untuk mengurangi emisi karbon dibanding hutan hujan tropis (Latupapua, 2011; Mandari et al, 2016).

Mangrove merupakan salah satu parameter Blue Carbon, karena perannya dalam memanfaatkan $\mathrm{CO} 2$ untuk fotosintesis dan menyimpannya dalam bentuk biomassa dan sedimen (Ati et al., 2014). mangrove merupakan salah satu hutan terkaya karbon di kawasan tropis, yang mengandung sekitar $1023 \mathrm{Mg}$ karbon per hektar (Donato et al., 2012). Beberapa tahun ini potensi penyimpanan karbon di ekosistem mangrove mulai mendapat perhatian sebagai salah satu jasa ekosistem yang berperan dalam mitigasi perubahan iklim (Kepel et al., 2017). Indonesia sendiri saat ini berada dalam urutan ketiga negara penghasil emisi CO2 terbesar di dunia (Imiliyana et al., 2012).

Mangrove bagi masyarakat di Kabupaten Belitung bukanlah tumbuhan asing, wilayah Belitung secara umum berdekatan dengan perairan laut mengakibatkan seluruh penduduk di Belitung akrab dengan kawasan pantai dan tumbuhan mangrovenya. Tegakan mangrove di Kabupaten Belitung termasuk dalam kategori yang sudah dewasa, dan termasuk hutan primer dengan tingkat intervensi antropogenik sangat rendah. Secara keseluruhan, mangrove di Kabupaten Belitung memiliki rata-rata kerapatan 1.000-1.500 pohon/ha nilai kerapatan tersebut termasuk dalam kategori yang cukup rapat.

Tujuan dari penelitian ini adalah mengestimasi simpanan karbon yang tersimpan pada atas permukaan tanah (Above ground).

\section{BAHAN DAN METODE}

Penelitian ini dilaksanakan selama 75 hari, terhitung dari 2 Maret 2020 sampai dengan 15 Mei 2020, yang berlokasi di kawasan mangrove Kabupaten Belitung, Provinsi Kepulauan Bangka Belitung. Peta titik lokasi pengambilan data dapat dilihat pada Gambar 1.

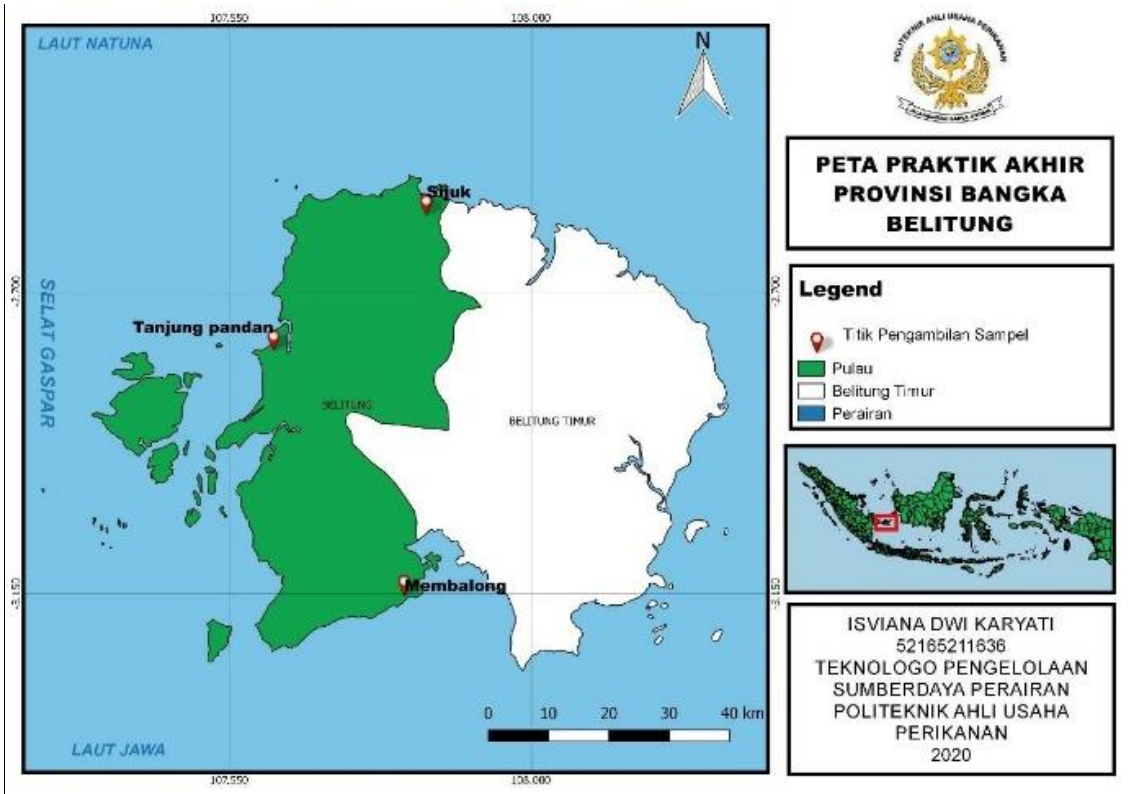

Gambar 1. Peta lokasi. 
Buletin JSJ, 3 (1), 2021, 43-51

Available online di: http://ejournal-balitbang.kkp.go.id/index.php/JSJ/index

Alat dan Bahan yang digunakan dalam kegiatan penelitian ini antara lain:

Tabel 1. Alat dan Bahan yang digunakan

\begin{tabular}{|c|c|c|c|c|}
\hline No & Nama Alat & Spesifikasi & Jumlah & Kegunaan \\
\hline 1 & Tali Transek & Panjang 100 meter & 1 buah & Batas Transek \\
\hline 2 & Tali Plot & Panjang 14 meter & 2 buah & Batas Identifkasi \\
\hline 3 & Meteran Kain & $\begin{array}{l}\text { Panjang } 150 \mathrm{~cm} \text { dengan } \\
\text { ketelitian } 1 \mathrm{~cm}\end{array}$ & 1 buah & $\begin{array}{l}\text { Untuk mengukur diameter } \\
\text { batang pohon mangrove. }\end{array}$ \\
\hline 4 & Patok Kayu & Panjang $150 \mathrm{~cm}$ & 5 buah & $\begin{array}{l}\text { Sebagai patokan tali transek dan } \\
\text { plot }\end{array}$ \\
\hline 5 & $\begin{array}{l}\text { Worksheet } \\
\text { Mangrove }\end{array}$ & Kertas Print & 3 lembar & $\begin{array}{l}\text { Lembar pengisian data } \\
\text { mangrove }\end{array}$ \\
\hline 6 & Papan jalan & $35 \times 22 \mathrm{~cm}$ & 1 buah & Membantu dalam menulis data \\
\hline 7 & alat tulis & Pulpen & 1 buah & Membantu dalam menulis data \\
\hline 8 & Roll meter & Panjang 50 meter & 1 buah & $\begin{array}{l}\text { Bertujuan untuk menentukan } \\
\text { jarak antar transek }\end{array}$ \\
\hline 9 & Kamera & $\begin{array}{l}\text { Kamera handpone / Kamera } \\
\text { digital }\end{array}$ & 1 buah & Alat dokumentasi \\
\hline 10 & GPS & Aplikasi handphone & 1 buah & Untuk menentukan titik koordinat \\
\hline 11 & Refraktometer & Ketelitian $0-100 \%$ & 1 buah & Mengukur salinitas perairan \\
\hline 12 & Termometer & Celcius & 1 buah & Mengukur suhu \\
\hline 13 & $\mathrm{pH}$ Meter & Indikator warna & 1 kotak & Mengukur $\mathrm{pH}$ perairan \\
\hline 14 & Plastic Zipper & $20 \times 30 \mathrm{~cm}$ & $\begin{array}{l}100 \\
\text { buah }\end{array}$ & Menyimpan sampel \\
\hline
\end{tabular}

\section{Analisa Blue Carbon}

Terdapat 4 cara utama untuk menghitung biomassa yaitu (i) sampling dengan pemanenan (Destructive sampling) secara in situ;(ii) sampling tanpa pemanenan (Non-destructive sampling) dengan data pendataan hutan secara in situ; (iii) Pendugaan melalui penginderaan jauh; dan (iv) pembuatan model. Untuk masing masing metode di atas, persamaan allometrik digunakan untuk mengekstrapolasi cuplikan data ke area yang lebih luas. Penggunaan persamaan allometrik standard yang telah dipublikasikan sering dilakukan, tetapi karena koefisien persamaan allometrik ini bervariasi untuk setiap lokasi dan spesies, penggunaan persamaan standard ini dapat mengakibatkan galat (error) yang signifikan dalam mengestimasikan biomassa suatu vegetasi (Hidayat 2017).

Estimasi biomassa pohon dilakukan dengan metode sampling tanpa pemanenan (nondestructive), dengan mengukur semua diameter at breast height ( $\mathrm{DBH}, 1.3 \mathrm{~m}$ ) mangrove, kemudian dilakukan perhitungan dengan model allometrik untuk menduga potensi biomassa dan simpanan karbonnya (Sutaryo, 2009). Sedangkan untuk mengestimasi karbon organik sedimen dilakukan dengan pengambilan sampel sedimen pada kedalaman 0-100 cm (Kauffman \& Donato, 2012).

\section{HASIL DAN PEMBAHASAN}

\section{Perhitungan Biomassa dan Kandungan Karbon}

Biomasa dapat dibedakan ke dalam dua kategori, yaitu biomasa di atas tanah (batang, cabang, ranting, daun, bunga dan buah) dan biomasa di dalam tanah (akar). Pada penelitian ini pengukuran biomasa mangrove dilakukan pada bagian di atas tanah (Above ground biomass). Biomassa merupakan tempat penyimpanan karbon atau dalam kata lain dinamakan sebagai rosot karbon (carbon sink). Sebagian besar biomassa terdiri dari karbon (C). Kandungan karbon pada tanaman menggambarkan berapa besar tanaman tersebut dapat mengikat CO2 dari udara. Karbon yang tersimpan dalam pohon dapat diketahui dengan menghitung kandungan biomassa 
Available online di: http://ejournal-balitbang.kkp.go.id/index.php/JSJ/index

pohon terlebih dahulu. Karbon merupakan komponen penting penyusun biomassa tanaman melalui proses fotosintesis yang terkandung sekitar 45-50\% dari biomassa (Akbar, 2019).

Dalam penelitian ini pengukuran biomasa dan kandungan karbon mangrove tidak dilakukan destructive sampling, melainkan menggunakan DBH dengan perhitungan metode allometrik. Adapun hasil perhitungan biomassa dan kandungan karbon di Kabupaten Belitung, yang disajikan pada tabel berikut:

Tabel 2. Hasil Biomassa dan Simpanan Karbon Setiap stasiun

\begin{tabular}{|c|c|c|c|c|c|}
\hline \multirow{2}{*}{ Stasiun } & \multirow{2}{*}{ Spesies } & $\begin{array}{l}\text { Jumlah } \\
\text { pohon }\end{array}$ & Kerapatan & Biomassa & Kandungan Karbon \\
\hline & & Batang & (Pohon/ha) & (Ton/ha) & (Ton C/ha) \\
\hline \multirow[b]{2}{*}{1} & Rhizophora apiculata & 301 & 1086,85 & 101,86 & 47,86 \\
\hline & $\begin{array}{l}\text { Rhizophora } \\
\text { mucronata }\end{array}$ & 156 & 563,28 & 286,67 & 134,73 \\
\hline \multicolumn{2}{|r|}{ Jumlah } & 457 & 1650,13 & 388,53 & 182,59 \\
\hline \multirow[b]{2}{*}{2} & Rhizophora apiculata & 316 & 1141,01 & 66,06 & 31,03 \\
\hline & $\begin{array}{l}\text { Rhizophora } \\
\text { mucronata }\end{array}$ & 30 & 108,32 & 15,99 & 7,53 \\
\hline \multicolumn{2}{|r|}{ Jumlah } & 346 & 1249,33 & 82,05 & 38,56 \\
\hline \multirow[b]{2}{*}{3} & Rhizophora apiculata & 236 & 852,15 & 117,47 & 55,22 \\
\hline & $\begin{array}{l}\text { Rhizophora } \\
\text { mucronata }\end{array}$ & 155 & 559,67 & 241,31 & 113,40 \\
\hline \multirow{2}{*}{\multicolumn{2}{|c|}{$\begin{array}{c}\text { Jumlah } \\
\text { Total keseluruhan }\end{array}$}} & 391 & 1411,82 & 358,78 & 168,62 \\
\hline & & 1,194 & 4377,28 & 829,36 & 389,75 \\
\hline
\end{tabular}

Keterangan:

Stasiun 1: Desa Sungai Padang Kecamatan Sijuk

Stasiun 2: Desa Juru Seberang Kecamatan Tanjung Pandan

Stasiun 3: Desa Tanjung Rusa Kecamatan Membalong

Berdasarkan tabel di atas hasil perhitungan Biomasa dan simpanan karbon pada ketiga stasiun untuk jenis Rhizophora apiculata pada stasiun ke-3 Desa Tanjung Rusa tertinggi biomassa dan simpanan karbonnya, dengan nilai biomassa 117,47 Ton/ha dan simpanan karbon 55,22 Ton $\mathrm{C} / \mathrm{ha}$, dengan kerapatan 1411,82 pohon/ha, diikuti stasiun ke-1 Desa Sungai Padang dengan nilai biomassa 101,86 Ton/ha dan simpanan karbon 47,86 Ton C/ha, dengan kerapatan 1650,13 pohon/ha. Serta biomassa dan simpanan karbon terendah terdapat pada stasiun ke-2 Desa Juru Seberang dengan nilai biomassa 66,06 Ton/ha dan simpanan karbon 31,03 Ton C/ha, dengan kerapatan 1249,33 pohon/ha.

Untuk jenis Rhizophora mucronata pada stasiun ke-1 Desa Sungai Padang tertinggi biomassa dan simpanan karbonnya, dengan nilai biomassa 286,67 Ton/ha dan simpanan karbon 134,73 Ton C/ha, dengan kerapatan 1650,13 pohon/ha, diikuti stasiun ke-3 Desa Tanjung Rusa dengan nilai biomassa 241,31 ton/ha dan simpanan karbon 113,40 Ton C/ha, dengan kerapatan 1411,82 pohon/ha. Serta biomassa dan simpanan karbon terendah terdapat pada stasiun ke-2 Desa Juru Seberang dengan nilai biomassa 15,99 Ton/ha dan simpanan karbon 7,53 Ton C/ha, dengan kerapatan 1249,33 pohon/ha. Kandungan karbon Rhizophora mucronata lebih besar dibandingkan Rhizophora apiculata dikarenakan diameter dan ukuran pohon Rhizophora mucronata. Besarnya suatu pohon dapat menggambarkan besarnya simpanan karbon (Kurniawan, 2018). Adapun nilai total karbon pada setiap stasiun dapat dilihat pada Gambar 2. 
Buletin JSJ, 3 (1), 2021, 43-51

Available online di: http://ejournal-balitbang.kkp.go.id/index.php/JSJ/index

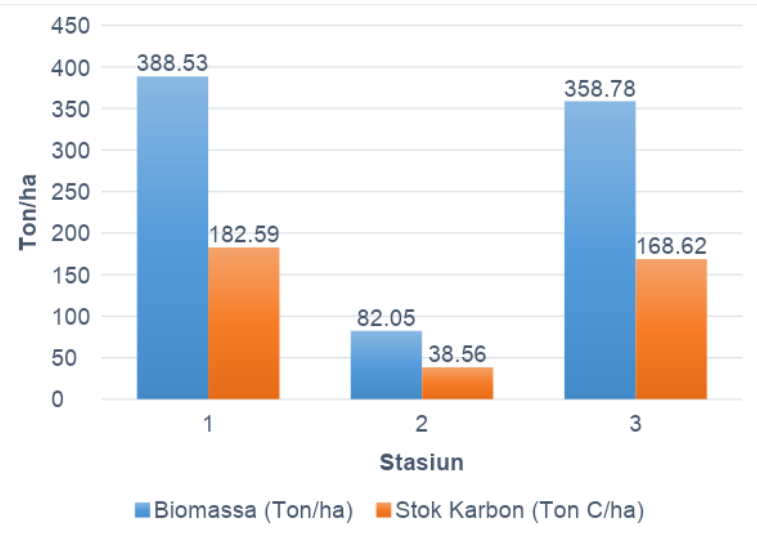

Gambar 2. Kandungan Biomassa dan Stok Karbon.

Untuk hasil perhitungan total biomassa dan kandungan karbon tertinggi terdapat pada stasiun ke-1 Desa Sungai Padang dengan nilai total biomassa 388,53 ton/ha dan total simpanan karbon 182,59 Ton C/ha dengan total kerapatan pohon 1650,13 pohon/ha, diikuti stasiun ke-3 Desa Tanjung Rusa dengan nilai total biomassa 382,48 ton/ha dan total simpanan karbon 179,76 Ton C/ha, dengan total kerapatan 1411,82 pohon/ha. Dan total biomassa dan total simpanan karbon terendah terdapat pada stasiun ke-2 Desa Juru Seberang dengan total biomassa 26,47 pohon/ha dan total simpanan karbon 12,44 Ton C/ha, dengan total kerapatan 1249,33 pohon/ha.

Nilai dari biomassa dan simpanan karbon masing-masing stasiun berbeda-beda hal tersebut dipengaruhi oleh jumlah pohon dan besarnya diameter batang pada masing-masing stasiun. Tabel 20 menjelaskan bahwa kerapatan mangrove mempunyai keterikatan terhadap kandungan karbon mangrove, semakin tinggi kerapatan semakin tinggi pula kandungan karbonnya (Kurniawan et al., 2019).

Selain jumlah pohon, diameter pohon juga mempengaruhi nilai biomassa, semakin besar diameter pohon semakin besar pula biomassa. Besarnya kandungan biomassa pada jenis Rhizophora sp dikarenakan jenis ini selalu hidup diperairan yang mendapatkan pasokan air secara berkala dan juga kondisi substratnya yang lebih banyak mengandung lumpur (Akbar, 2019).

Selain melindungi daerah pesisir dari abrasi, tanaman mangrove mampu menyerap emisi yang terlepas dari lautan dan udara. Dengan cara penyerapan karbon untuk proses fotosintesis, hasil dari fotosisntesis tersebut menghasilkan oksigen, kemudian oksigen tersebut akan dilepas ke atmosfer dan akan terlarut keperairan, tingginya kandungan oksigen di perairan akan mencirikan tingginya kelimpahan organisme fitoplankton pada perairan tersebut yang membuat perairan tersebut subur. Apabila perairan tersebut subur maka ikan dan biota yang ada di perairan tersebut dapat hidup dengan baik, begitupun sebaliknya apabila oksigen di periran rendah maka ikan dan biota di perairan tersebut akan mengalami kematian karena kekurangan oksigen.

\section{Serapan Karbon $\mathrm{CO}_{2}$ pada Mangrove}

Blue carbon merupakan konsep baru dalam mengurangi emisi CO2. Blue carbon adalah pemanfaatan ekosistem pesisir (mangrove, lamun, etuari dan rawa payau) dalam menyerap $\mathrm{CO} 2$ melalui fotosintesis dan menyimpan (sequestration) dalam bentuk biomassa (Hardjana. 2010; Donato et al., 2011). Setelah nilai kandungan karbon didapat, selanjutnya dilakukan penghitungan penyetaraan Stok $\mathrm{C}$ ke serapan $\mathrm{CO}_{2}$ Hasil serapan karbon $\mathrm{CO}_{2}$ pada Mangrove dapat dilihat pada Tabel 3. 
Buletin JSJ, 3 (1), 2021, 43-51

Available online di: http://ejournal-balitbang.kkp.go.id/index.php/JSJ/index

Tabel 3. Serapan Karbon pada Mangrove

\begin{tabular}{cccc}
\hline & Stasiun & Jenis Mangrove & Serapan Karbon Perjenis (g/pohon) \\
\hline 1 & Desa Sungai Padang & Rhizophora apiculata & 81,47 \\
& & Rhizophora mucronata & 229,35 \\
\cline { 2 - 3 } & Total & $\mathbf{3 1 0 , 8 2}$ \\
\hline 2 Desa Juru Seberang & Rhizophora apiculata & 36,70 \\
& Rhizophora mucronata & 8,91 \\
\hline & Total & $\mathbf{4 5 , 6 1}$ \\
\hline \multirow{2}{*}{ Desa Tanjung Rusa } & Rhizophora apiculata & 99,11 \\
& Rhizophora mucronata & 203,54 \\
\hline \multicolumn{2}{c}{ Total Keseluruhan } & $\mathbf{3 0 2 , 6 5}$ \\
\hline & Total & $\mathbf{6 5 9 , 0 8}$ \\
\hline
\end{tabular}

Berdasarkan tabel di atas hasil perhitungan serapan karbon pada ketiga stasiun untuk jenis Rhizophora apiculata pada stasiun ke-3 Desa Tanjung Rusa tertinggi nilai serapan karbonnya dengan nilai 99,11 g/pohon, diikuti stasiun 1 Desa Sungai Padang dengan nilai serapan karbon $81,47 \mathrm{~g} /$ pohon dan yang paling rendah nilai serapan karbonnya terdapat pada stasiun 2 Desa Juru Seberang dengan nilai 36,70.

Untuk jenis Rhizophora mucronata pada stasiun ke-1 Desa Sungai Padang tertinggi nilai serapan karbonnya, dengan nilai 229,35 g/pohon, diikuti stasiun 3 Desa Tanjung Rusa dengan nilai serapan karbon $203,54 \mathrm{~g} /$ pohon dan yang paling rendah nilai serapan karbonnya terdapat pada stasiun 2 Desa Juru Seberang dengan nilai 8,91 g/pohon. Adapun nilai serapan karbon pada setiap stasiun dapat dilihat pada Gambar 3.

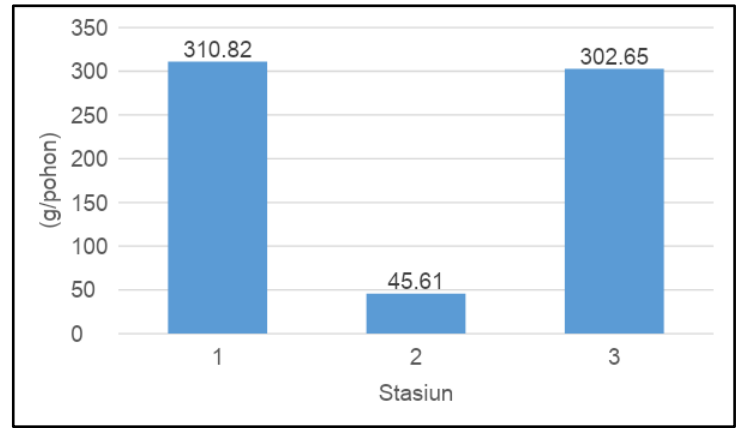

Gambar 3. Serapan Karbon $\mathrm{CO}_{2}$.

Berdasarkan Gambar 3, diketahui bahwa nilai serapan karbon tertinggi terdapat pada stasiun 1 Desa Sungai Padang dengan nilai serapan karbon 310,82 g/pohon, kemudian stasiun 3 Desa Tanjung Rusa dengan nilai serapan karbon 302,65, dan nilai serapan karbon terendah terdapat pada stasiun 2 Desa Juru Seberang dengan nilai serapan karbon 45,61 g/pohon.

Besarnya nilai serapan karbon pada stasiun 3 diduga karena diameter dan tegakan pohon di lokasi pengamatan yang sudah termasuk kategori dewasa, sedangkan rendahnya serapan karbon pada stasiun 2 diduga karena diameter pohon yang masih tergolong kecil. Hasil yang diperoleh dari hasil pengamatan yang dilakukan yaitu adanya perbedaan nilai $\mathrm{CO}_{2} / \mathrm{g}$ tiap stasiun. Hal ini bisa saja terjadi dikarenakan jumlah pohon, jenis pohon, dan sebaran kelas diameter, sehingga berpengaruh terhadap jumlah serapan $\mathrm{CO}_{2}$ yang dihasilkan. Besarnya jumlah karbon yang terikat dalam suatu tanaman dapat menggambarkan seberapa besar kemampuan tanaman tersebut dalam mengikat gas CO2 dari atmosfer (Frananda et al. 2015; Maizaldi et al., 2019). Besarnya serapan karbon perjenis dari gabungan setiap stasiun dapat dilihat pada Gambar 4. 
Buletin JSJ, 3 (1), 2021, 43-51

Available online di: http://ejournal-balitbang.kkp.go.id/index.php/JSJ/index

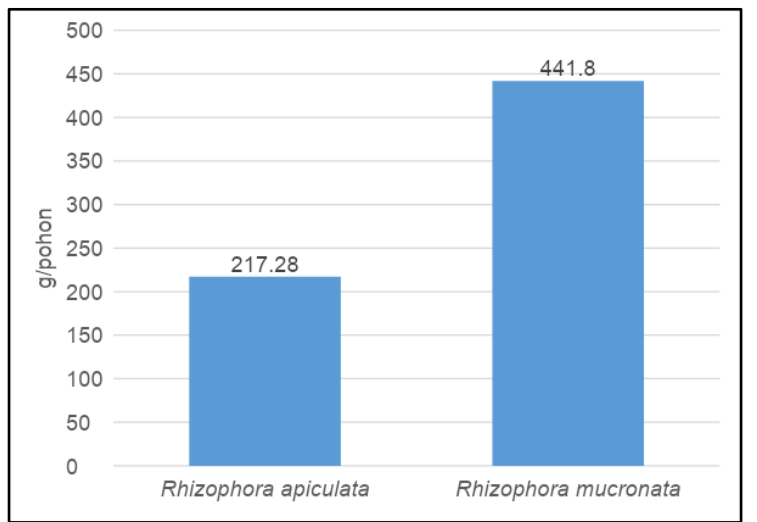

Gambar 4. Serapan Karbon $\mathrm{CO}_{2}$ Perjenis.

Pada Gambar 4, dapat diketahui bahwa mangrove jenis Rhizophora mucronata merupakan jenis yang paling besar dalam mengikat serpan $\mathrm{CO}_{2}$ di udara dengan nilai serapan 441,8 g/pohon dan jenis Rhizophora apiculata dapat mengikat serapan $\mathrm{CO}_{2}$ dengan nilai serapan $217,28 \mathrm{~g} /$ pohon. Letak geografis Kabupaten Belitung yang diapit laut menjadikan aktivitas nelayan sangat tinggi, tingginya aktivitas nelayan tentunya dapat menyebabkan polusi udara yang dikeluarkan dari mesin kapal dan kegiatan pertambangan di darat, oleh sebab itu fungsi mangrove sebagai pengikat karbon di Kabupaten Belitung sangat diperlukan. Rhizophora mucronata merupakan penyumbang serapan karbon terbesar oleh karena itu penanaman bibit mangrove jenis Rhizophora mucronata sangat diperlukan guna menjaga stabilitas lingkungan. Besarnya serapan karbon per hektar dapat dilihat pada Gambar 5.

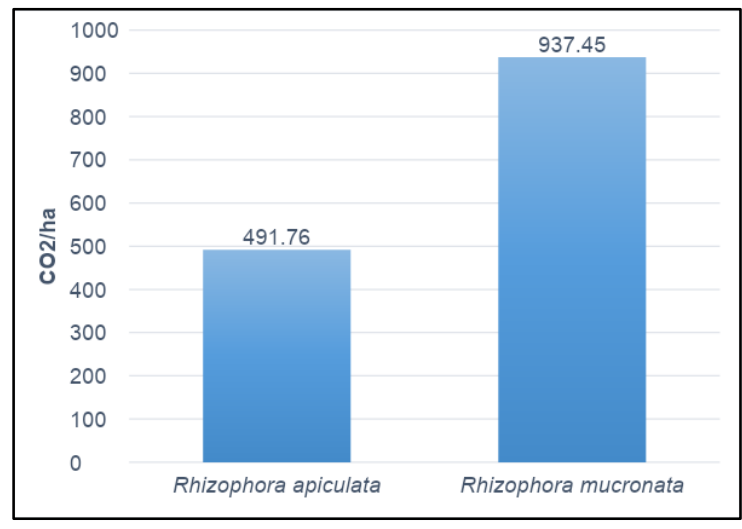

Gambar 5. Serapan karbon $\mathrm{CO}_{2}$ perhektar.

Berdasarkan Gambar 5, dapat diketahui bahwa mangrove jenis Rhizophora mucronata merupakan jenis yang paling besar dalam mengikat serpan $\mathrm{CO}_{2}$ di udara dengan nilai serapan 937,45 ton $\mathrm{CO}_{2}$ /ha dan jenis Rhizophora apiculata dapat mengikat serapan $\mathrm{CO}_{2}$ dengan nilai serapan 491,76 ton $\mathrm{CO}_{2} /$ ha. Besarnya serapan karbon pada suatu jenis mangrove tidak terlepas dari tinggi dan diameter batang pohon. Batang merupakan bagian kayu yang tersusun oleh selulosa. Selulosa merupakan molekul gula linear yang tersusun oleh karbon, sehingga makin tinggi selulosa maka kandungan karbon akan semakin tinggi. Jika diameter semakin besar maka tanaman diduga memiliki potensi selulosa dan zat penyusun kayu akan lebih besar sehingga potensi serapan karbon semakin meningkat (Afkar et al, 2014; Irsadi et al., 2017). Berdasarkan hasil penelitian Heriyanto dan Heriyanto \& Subiandono (2012) Rhizophora sp. memiliki nilai serapan karbon dioksida tertinggi yaitu 398,60 ton $\mathrm{CO}_{2} /$ ha. 
Available online di: http://ejournal-balitbang.kkp.go.id/index.php/JSJ/index

\section{Potensi Ekonomi Simpanan Karbon}

Sebagai suatu ekosisten yang memiliki nilai ekonomi khususnya dalam nilai kandungan karbon, maka pengukuran nilai ekonomi karbon di suatu ekosistem mangrove dapat dilakukan. Pengukuran nilai ekonomi dilakukan berdasarkan asumsi nilai jual rata-rata karbon. Harga karbon di pasar wajib senilai US\$16 tC/ha atau setara dengan US\$ $21 \mathrm{tC} / \mathrm{ha}$ (Auliansyah et al., 2020). Nilai tukar rupiah terhadap US\$ pada tanggal 25 Juli 2020 senilai Rp. 14,602 yang artinya harga karbon Rp 306,642. Potensi nilai ekonomi karbon di Kabupaten Belitung dapat dilihat pada Tabel 4.

Tabel 4. Potensi Ekonomi Simpanan Karbon

\begin{tabular}{lllllll}
\hline Jenis & $\begin{array}{l}\text { Rata-rata Simpanan } \\
\text { Karbon / ha }\end{array}$ & $\begin{array}{l}\text { Luas } \\
\text { Mangrove } \\
\text { (ha) }\end{array}$ & $\begin{array}{l}\text { Total } \\
\text { Karbon } \\
\text { (tC) }\end{array}$ & $\begin{array}{l}\text { Harga } \\
\text { Karbon } \\
\text { (Rp) }\end{array}$ & $\begin{array}{l}\text { Ekonomi } \\
\text { Karbon } \\
\text { Rp/ha/thn }\end{array}$ & $\begin{array}{l}\text { Total Ekonomi } \\
\text { Karbon (Rp) }\end{array}$ \\
\hline $\begin{array}{c}\text { Simpanan } \\
\text { Karbon }\end{array}$ & 64,95 & $6.606,94$ & 389,75 & 306.642 & 19.916 .398 & 131.716 .898 .650 \\
\hline
\end{tabular}

Hasil pengamatan data lapangan menjelaskan bahwa jumlah kandungan karbon yang tersimpan pada hutan mangrove di Kabupaten Belitung dengan menggunakan persamaan allometrik diperoleh sebesar 389,75 $\mathrm{C}$ ton/ha. Nilai ekonomi karbon yang terdapat pada Kabupaten Belitung memiliki nilai sebesar Rp. 19.916 .398 ha/tahun dan memiliki nilai ekonomi total karbon senilai Rp. 131.716.898.650 dengan simpanan karbon 389,75 C ton/ha dengan luas hutan mangrove 6.606,94 ha.

\section{KESIMPULAN}

Mangrove di Kabupaten Belitung tergolong sangat padat dan didominasi oleh Rizhopra mucronata, dan Rhizopora apiculata. Kerapatan mangrove berbanding lurus dengan besarnya biomassa, stok, dan serapan karbon sehingga perlu adanya peraturan untuk menjaga kelestarian mangrove agar kualitas udara dapat terjaga dengan baik. Stok dan serapan karbon mangrove tiap stasiun berbeda berdasarkan kategori pertumbuhan mangrove, besarnya nilai serapan karbon pada stasiun 3 diduga karena diameter dan tegakan pohon di lokasi pengamatan yang sudah termasuk kategori dewasa, sedangkan rendahnya serapan karbon pada stasiun 2 diduga karena diameter pohon yang masih tergolong kecil.

\section{DAFTAR PUSTAKA}

Afkar, A., Djufri, D., \& Sarong, M. A. (2014). Asosiasi Makrozoobenthos Dengan Ekosistem Mangrove Di Sungai Reuleng Leupung, Kabupaten Aceh Besar. Jurnal EduBio Tropika, 2(2).

Akbar, N., Marus, I., Haji, I., Abdullah, S., Umalekhoa, S., Ibrahim, F. S., Ahmad, M., Ibrahim, A., Kahar, A., \& Tahir, I. (2017). Struktur Komunitas Hutan Mangrove Di Teluk Dodinga, Kabupaten Halmahera Barat Provinsi Maluku Utara. Jurnal Enggano, 2(1), 78-89.

Ati, R. N. A., Rustam, A., Kepel, T. L., Sudirman, N., Astrid, M., Daulat, A., Mangindaan, P., Salim, H. L., \& Hutahaean, A. A. (2014). Stok Karbon dan Stuktur Komunitas Mangrove Sebagai Blue Carbon di Tanjung Lesung, Banten. Jurnal Segara, 10(2), 119-127.

Auliansyah, A., Kusumastanto, T., Sadelie, A., Aprianti, Y., Sulindrina, A., \& Nurfadillah, N. (2020). Valuasi ekonomi dan penilaian kerusakan kawasan ekosistem mangrove di pulau tanakeke kabupaten takalar. INOVASI, 16(1), 72-83.

Donato, D., Kauffman, J. B., Murdiyarso, D., Kurnianto, S., Stidham, M., \& Kanninen, M. (2012). Mangrove adalah salah satu hutan terkaya karbon di kawasan tropis. Center for International Forestry Research (CIFOR), Bogor, Indonesia 


\section{Buletin JSJ, 3 (1), 2021, 43-51}

Available online di: http://ejournal-balitbang.kkp.go.id/index.php/JSJ/index

Frananda, H., Hartono, H., \& Jatmiko, R. H. (2015). Komparasi Indeks Vegetasi Untuk Estimasi Stok Karbon Hutan Mangrove Kawasan Segoro Anak Pada Kawasan Taman Nasional Alas Purwo Banyuwangi, Jawa Timur. Majalah Ilmiah Globe, 17(2), 113-123.

Hardjana, A. K. (2010). Potensi biomassa dan karbon pada hutan tanaman Acacia mangium di HTI PT. Surya Hutani Jaya, Kalimantan Timur. Jurnal Penelitian Sosial dan Ekonomi Kehutanan, 7(4), 29080.

Heriyanto, N. M., \& Subiandono, E. (2012). Komposisi dan struktur tegakan, biomasa, dan potensi kandungan karbon hutan mangrove di Taman Nasional Alas Purwo. Jurnal Penelitian Hutan dan Konservasi Alam, 9(1), 023-032.

Hidayat, T. 2017. Model Penduga Biomassa Bagian Atas (Above-Ground) Dan Bawah Tanah (Below-Ground) Kelompok Jenis Sonneratia spp (Doctoral dissertation, Bogor Agricultural University (IPB)).

Imiliyana, A., Muryono, M., \& Purnobasuki, H. (2012). Estimasi stok karbon pada tegakan pohon Rhizophora stylosa di pantai Camplong, Sampang-Madura. Jurusan Biologi Fakultas MIPA. Institut Teknologi Sepuluh November.

Irsadi, A., Martuti, N. K. T., \& Nugraha, S. B. (2017). Estimasi Stok Karbon Mangrove Di Dukuh Tapak Kelurahan Tugurejo Kota Semarang. Sainteknol: Jurnal Sains dan Teknologi, 15(2), 119-128.

Kauffman, J. B., \& Donato, D. C. (2012). Protocols for the measurement, monitoring and reporting of structure, biomass, and carbon stocks in mangrove forests. Citeseer.

Kepel, T. L., Suryono, D. D., Ati, R. N. A., Salim, H. L., \& Hutahaean, A. A. (2017). Nilai Penting Dan Estimasi Ekonomi Simpanan Karbon Vegetasi Mangrove Di Kecamatan Kema, Sulawesi Utara. Jurnal Kelautan Nasional, 12(1), 19-26.

Kurniawan, A., Sari, S. P., Asriani, E., Kurniawan, A., Sambah, A. B., Triswiyana, I., \& Prihanto, A. A. (2019). Kapasitas Hidrolisis Bakteri Pendegradasi Selulosa Dari Ekosistem Mangrove. Journal of Tropical Marine Science, 2(2), 76-82.

Kurniawan, C. A., Pribadi, R., Juliadi, I. A., \& Kuslarsono, R. (2018). Dugaan Serapan Karbon Pada Vegetasi Mangrove Di Pantai Maron Semarang: Studi Kasus Rehabilitasi Mangrove Di Ekowisata Maroon Mangrove Edu Park 2011-2018 oleh PT. PHAPROS Tbk. Prosiding Seminakel, 1(1).

Latupapua, M. J. (2011). Keanekaragaman Jenis Nekton Di Mangrove Kawasan Segoro AnakTaman Nasional Alas Purwo. Jurnal A groforestri, VI (2).

Maizaldi, M., Amin, B., \& Samiaji, J. 2019. Estimasi Jumlah Stok Karbon Yang Tersimpan di Lahan Basah Desa Sungai Tohor Kecamatan Tebing Tinggi Timur Kabupaten Kepulauan Meranti Provinsi Riau. Dinamika Lingkungan Indonesia, 6(2), 60-66.

Mandari, D. Z., gunawan, H., \& ISDA, M. N. (2016). Penaksiran biomassa dan karbon tersimpan pada ekosistem hutan mangrove di Kawasan Bandar Bakau Dumai. Jurnal Riau Biologia, $1(1), 17-23$.

Sutaryo, D. (2009). Penghitungan Biomassa Sebuah pengantar untuk studi karbon dan perdagangan karbon. Wetlands International Indonesia Programme. Bogor. 